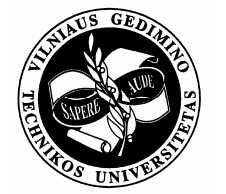

\title{
THE ANALYSIS OF NON-STRESS EFFECTS ON HISTORICAL STONE BRIDGE STRUCTURES (MONITORING, THEORETICAL ANALYSIS, MAINTENANCE)
}

\author{
Jiří Witzany ${ }^{1}$, Radek Zigler ${ }^{2}$ \\ Dept of Building Structures, Faculty of Civil Engineering, Czech Technical University in Prague, \\ Thákurova 7, Prague 6, 166 29, Czech Republic.E-mail. ${ }^{1}$ witzany@fsv.cvut.cz, ${ }^{2}$ zigler@fsv.cvut.cz \\ Received 14 July 2006; accepted 30 Nov 2006
}

\begin{abstract}
Due to non-stress cyclic effects of temperature and moisture, stone bridge structures are subjected to deformations, a gradual growth of permanent deformations, crack development and subsequent disintegration of the stone masonry of bridge vaults. A theoretical analysis of the stress-state and deformations of the stone bridge structure caused by nonstress effects and the in-situ monitoring of deformation changes of the breast walls and the bridge vaults of the historic structure of Charles Bridge (from the mid- $14^{\text {th }}$ century) manifested a response and a growth in permanent deformations and disintegration of the stone bridge structure due to the effects of temperature and moisture. The behaviour of the bridge structure is significantly affected by the interaction of the vault bridge structure with the bridge body filler when exposed to the above-mentioned non-stress effects. Special attention must be paid to the spacing effect of filling layers on the stone bridge structure. When repairing historical stone bridge structures, the rehabilitation methods commonly used increase the total rigidity of the stone bridge structure and thus its sensitivity to non-stress effects caused by changes in temperature.
\end{abstract}

Keywords: cyclic effects, permanent deformations, disintegration, non-stress effects, interaction, moisture.

\section{Introduction}

A reliable design of conservation and prevention of failures of historical stone bridge structures requires theoretical and experimental research including the problems of the historical stone structure in relation to mineralogical and petrographic aspects, the problems of chemical and biochemical degradation processes and the effect of these processes on the properties of building materials and the service life of the historical structure as a whole. A component part of this research is long-term monitoring of the results of non-stress effects on the strain and cracking in the bridge structure. A special focus must be concentrated on the effect of temperature changes on the stress and deformation of the stone bridge structure and its interaction with the bridge body filler. The possibility of application of electronic speckle pattern interferometry (EPSI) in various configurations (reference beam or shear) as well as double exposure speckle photography is referred to eg in [1]. The problems of methodology and strategy for fatigue damage assessment and life prediction of existing bridge structures with online structural health monitoring data are pointed out by the authors in [2].

A significant factor in terms of the response of the stone structure to non-stress effects is the interaction of the stone bridge structure and the bridge body filler and its interaction with the breast walls, which prominently affects mainly the vertical deformations of the bridge vaults. The undesirable effect of the interaction of the bridge body layers is shown eg in the case of their structurally efficient contact with the breast walls and the bridge vaults. Experience of long term monitoring of the structure of brickwork arch bridges in an attempt to quantify the effect of both temperature and seasonal variations on the pressures in the arch is summed up in [3]. The problem of monitoring ancient buildings by the thermal method is described in [4].

Theoretical analyses and the monitoring of deformations show that the increased rigidity of the bridge body filler and its interaction with the stone structure had a negative effect on the behaviour of the bridge structure contributing to its gradual mechanical disintegration.

A serious problem is a high moisture content of the bridge body filler resulting from rainwater leakage through the faulty damp proofing and its contamination by salts being the cause of chemical, biochemical and physical degradation processes deteriorating, step by step, the stone structure and impairing its service life. The problems of continuous monitoring of the moisture content, mainly with a view to obtaining fully repeatable data are treated eg in [5].

The different physical and mechanical characteristics of individual stone blocks, the variability in the thickness and the properties of the bridge body filling layers and the contact of the filler with the stone bridge structure (of vault type), which is difficult to define, all this makes the creation of explicit computation models (structural, material, loading) difficult. For this reason, the comparison of data experimentally obtained through a long-term monitoring of deformations and strain with the results of the theoretical (numerical) analysis represents a basic prerequisite for the verification of the computation models used. The problems of sophisticated non-linear failure analyses, in-situ testing and monitoring of historical structures are described eg in [6-10]. 


\section{Stone structure of Charles Bridge}

Among prominent structures that testify to the advanced level of mediaeval construction technology there are stone bridge structures of the $13^{\text {th }}$ century built in Regensburg and Avignon and the stone bridge from the $14^{\mathrm{th}}$ century in Prague (Fig 1).

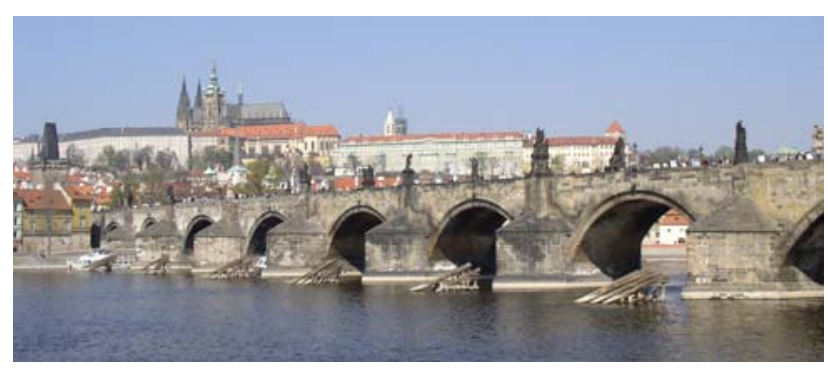

Fig 1. Charles Bridge with 16 arches and a clear span of $16,62 \mathrm{~m}$ to 23,38 . The overall bridge length is $515,76 \mathrm{~m}$ and it is $9,4 \mathrm{~m}$ wide. The dimensions of massive stone piers at the arch footing range between $8,5 \mathrm{~m}$ and $10,84 \mathrm{~m}$ by $24,0 \mathrm{~m}$ to $25,0 \mathrm{~m}$. Pier heads have been "sharpened" against the water stream at an angle of $65^{\circ}$. The bridge construction started in 1357 and was completed in 1406

The monitoring of deformations of the stone structure of Charles Bridge proved the gravity and relevance of non-stress effects (temperature, moisture content) on cyclic deformations and permanent strain accompanied by a gradual disintegration of its stone masonry, growing tilt of the breast walls and development of cracks in the masonry of the stone bridge structure. Each deformation cycle is accompanied by a gradual growth in permanent deformations. The „unmanifested“ primary deformation due to eg a temperature change causes a mechanical state of tension, and it is mainly the tensile stresses thus arising that contribute to the development of tensile cracks in the stone masonry.

An inseparable part of the structure of Charles Bridge are the breast walls mounted on the bridge vaults and running continuously across the bridge piers, mostly without expansion joints, reinforced at the points of piers with stone masonry pillars which, at the same time, serve as pedestals for statues. Like the piers and the vault bridge arches, the breast walls are built of stone masonry using bush-hammered, mostly sandstone blocks of various composition and age, originating from various localities and bound to lime mortar from sandstone stucco and hydraulic lime, later with a cement admixture. The sandstone and feldspathic sandstone were used for construction, while during the repair of the bridge piers and spans after the flood of 1890 siliceous sandstone of the Cretaceous age and kaolinitic sandstone were used.

The high breast walls originally showed greater flexibility, which was enhanced by lime mortar in the joints between the stone blocks and, most probably, also partially unfilled vertical head joints between the blocks. During successive repairs, the breast walls' masonry was gradually strengthened by filling in the joints. During the last repair (1966-1975), the breast walls in some spans
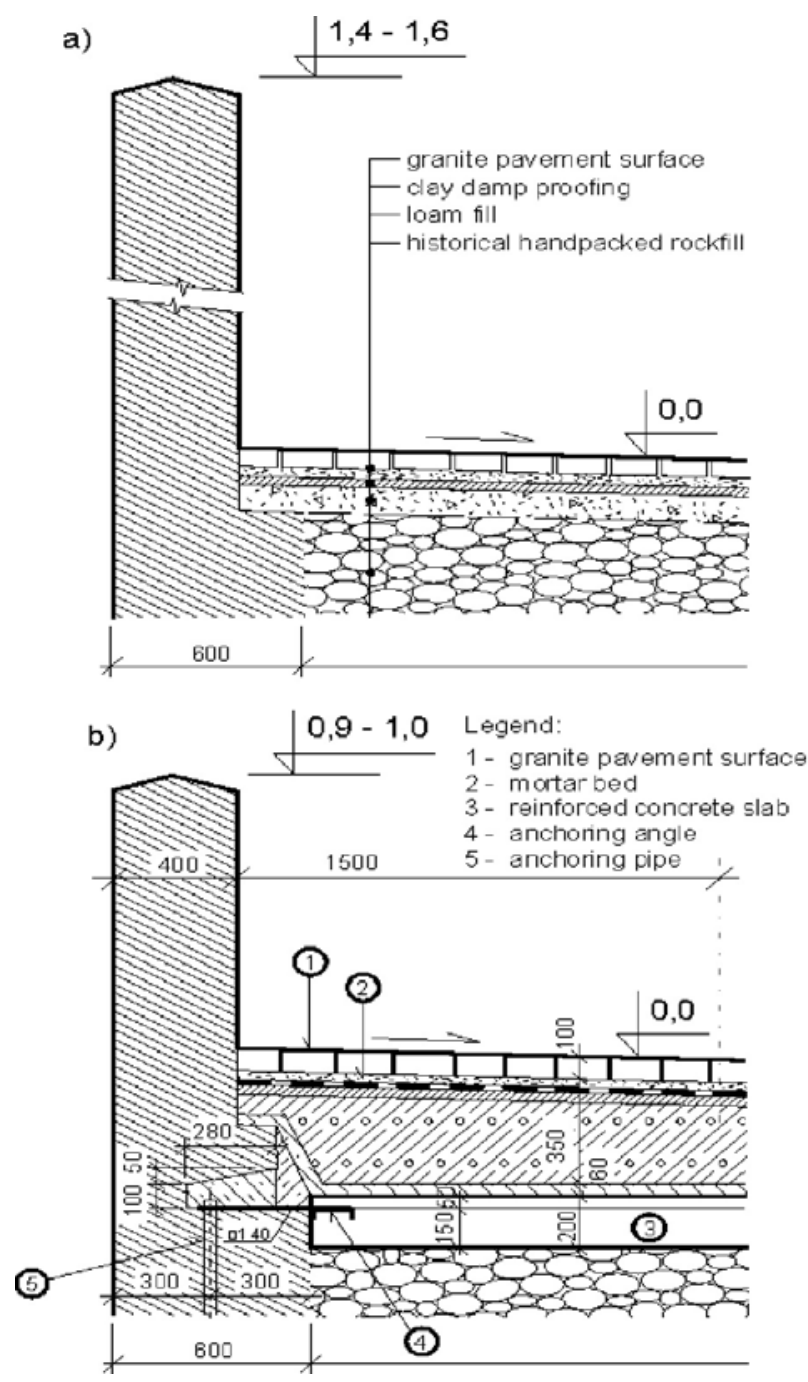

Fig 2. Historical arrangement of the bridge body (according to V. Mencl) (a); a scheme of reinforced concrete slab anchorage in the breast wall (design plan, repair of 1966-1975) (b)

(VIII, X) were partially dismantled to the rainwater spout level. Vertical or inclined boreholes were made for mounting and grouting steel anchoring pipes passing through the breast walls and anchored in the bridge vaults 1,2 $\mathrm{m}$ apart. The extent of this treatment has not been reliably recorded. The last implemented probes (spans V, VIII, XII, 7/2002) failed to prove the execution of this designed treatment. In their lower part, the breast walls are approx 0,6 m thick, while in their upper part their thickness at a height of about $1,5 \mathrm{~m}$ goes down to approx $0,4 \mathrm{~m}$.

The original pier filler and the material to level the layers of different thickness above the vault arches was arenaceous marl rockfill composed of hewn stone or stone masonry made up of chips of various sizes bound together by lime mortar. This layer was overlaid with loamy backfill and cob and an insulation layer of cast clay. The final finish consisted of stone pavement embedded in loamy sand. The arenaceous marl rockfill or the stone masonry made up of chips of various sizes bound together by lime mortar, which served for transferring the load from the bridge deck onto the bridge vaults, 
did not load the breast walls with horizontal spacing stresses. Undressed arenaceous marl blocks only discretely joined together by lime mortar in bed joints, limited the intense interaction between the bridge body filler, the breast walls and the bridge vaults, namely in relation to the effect of cyclic deformations of the bridge arches (Fig 11) due to temperature and moisture effects, and thus the occurrence of predominantly transverse stresses preceding the appearance of longitudinal cracking on the underside of the bridge vaults. The stone pavement with loamy joint filler allowed free expansion of individual pavement blocks. The back side of the stone bridge vaults was probably treated with an insulation layer of loamy clay, which was supposed to drain off the water absorbed from the bridge deck surface into the pier footings.

During the repair of Charles Bridge in 1966-1975, in some bridge spans the arenaceous marl rockfill was partially grouted with a cement mix (Colcrete), the loamy backfill and the cob were replaced by screed concrete, which was, according to the project, overlaid with a diagonal mesh of reinforcing steel with a diameter of $14 \mathrm{~mm}$, steel 10425, concreted on both sides with a layer of a total thickness of $0,12-0,20 \mathrm{~m}$. The project presumed anchorage of the diagonal mesh into the breast walls by means of clip angles and steel grouting pipes passing through the breast walls (Fig 2). On the top of this layer, a layer of expanded-clay concrete was performed and levelled with a grade slab and damp proofing. Exploratory dug holes (6 in 1983, 3 in 2003) and boreholes (12 in 2000) proved considerable differences in the composition and thickness of the bridge body filling layers, in the workmanship quality and in their mineralogical, chemical, physical and mechanical properties (the thickness of expanded-clay concrete ranging from 0,15 to $0,50 \mathrm{~m}$, some exploratory holes failed to detect the concrete slab or the diagonal meshing etc Fig 3).

Theoretical analyses and the monitoring of deformations show that the increased rigidity of the bridge body filler and its interaction with the stone bridge structure had a negative effect on the behaviour of the stone bridge structure contributing to its gradual mechanical disintegration.

The high moisture content of the bridge body filler resulting from rainwater leakage through the faulty damp proofing and its contamination by salts are the cause of chemical, biochemical and physical degradation processes deteriorating, step by step, the stone bridge structure and impairing its service life.

\section{Chemical and biochemical degradation of the stone bridge structure}

The effect of inorganic salts input in stone either in the form of deicing salts or by reactions with atmospheric pollutants is responsible for considerable loads of namely the sandstone blocks of Charles Bridge. In order to reach a moisture balance between the interior and exterior environment during stone moistening, due to their hygroscopic properties, the salts accumulate or release water during their transition into a crystalline form. Both crystallisation from a solution and hydration changes of salts are accompanied by hydration and crystallisation pressures. These pressures reach high values $\left(\mathrm{CaSO}_{4} \cdot 2 \mathrm{H}_{2} \mathrm{O}-\right.$ $111 \mathrm{MPa}, \mathrm{NaCl} \cdot 2 \mathrm{H}_{2} \mathrm{O}-130 \mathrm{MPa}$ ), thus affecting the development of expansion joints or microcracks in stone. Due to high concentrations of salts in stone, we have all

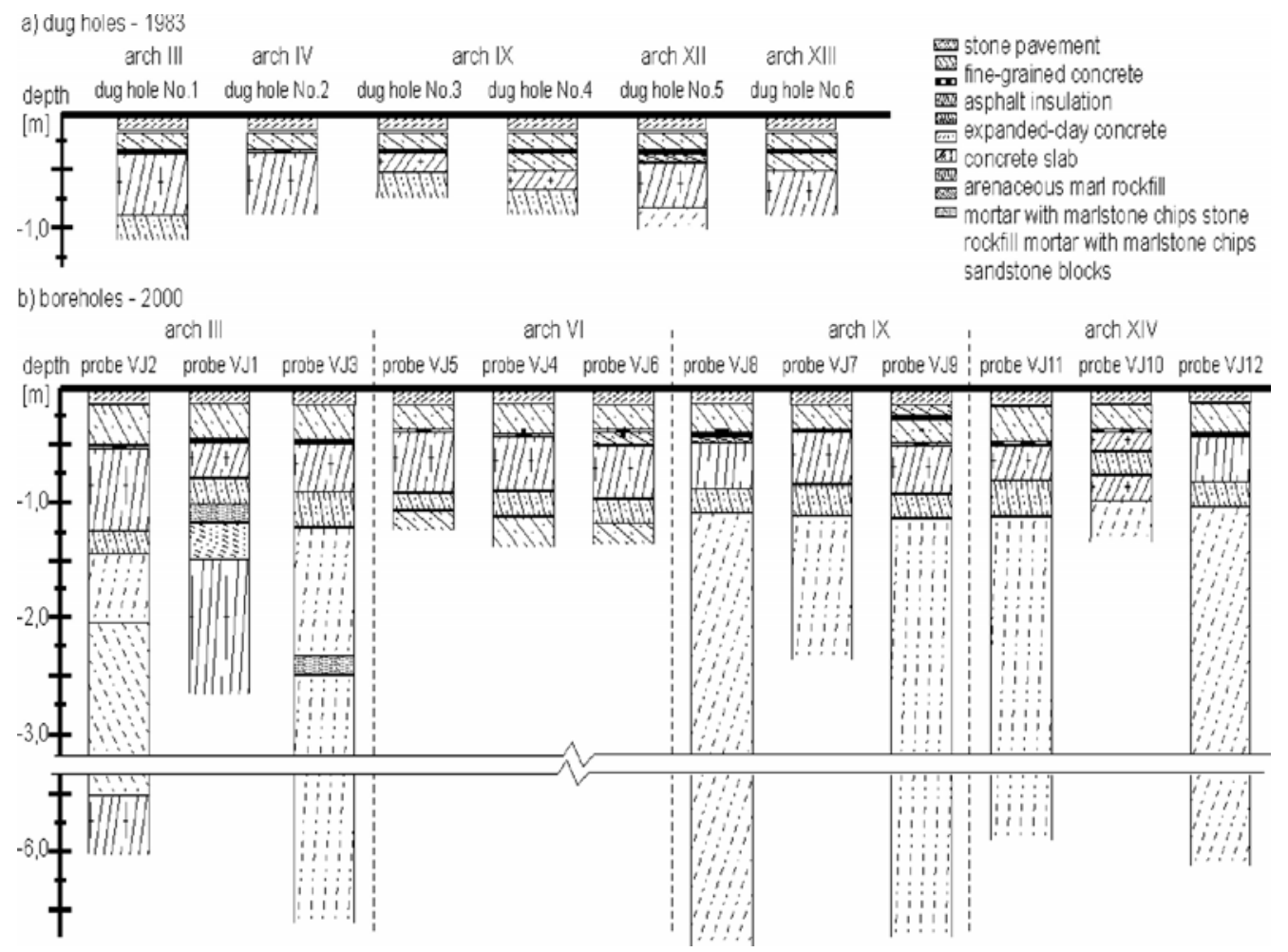

Fig 3. Composition of the bridge body filling layers as recorded in test holes and applied in the repair project of 1967-1975 (for bridge pier and bridge span numbering, Fig 5) 
reasons to believe that hydration and crystallisation pressures participate in the appearance of microcracks in stone, the further growth of which increases the area of reaction surfaces of the building material. In this way (together with structural failures) a system of cracks develops, which poses a threat for the stability of surface stone layers.

As was shown by previous chemical analyses (according to Wasserbauer), the microbes also produce large quantities of organic acids in stone, which in turn release $\mathrm{Ca}^{2+}$ from the minerals in stone and in other structural materials. Among the prominent secondary metabolites, $\mathrm{KNO}_{3}$ must be named, which participates in the growth of salt crusts, thus significantly degrading the surface stone texture. Due to the fact that sulphur bacteria have been found at numerous places, it is very likely that a certain proportion of sulphur crusts and sulphates in stone are also formed by microorganisms. All above-mentioned microbe metabolites weaken the binding stone component and attack stone clay minerals forming salts (nitrates, sulphates, citrates, salicylates, oxalacetates, formates etc), which block up or open the pores in stone and contribute to the transformation of minerals contained in stone (Fig 4). Hydration and recrystallisation pressures by microbial salts in stone accelerate the growth of microcracks in stone and increase the instability of surface stone layers. Accelerated total aging of sandstone blocks is further facilitated by the reversible moisture gradient, which allows both the washing out and migration of easily soluble salts into the depth of sandstone blocks.
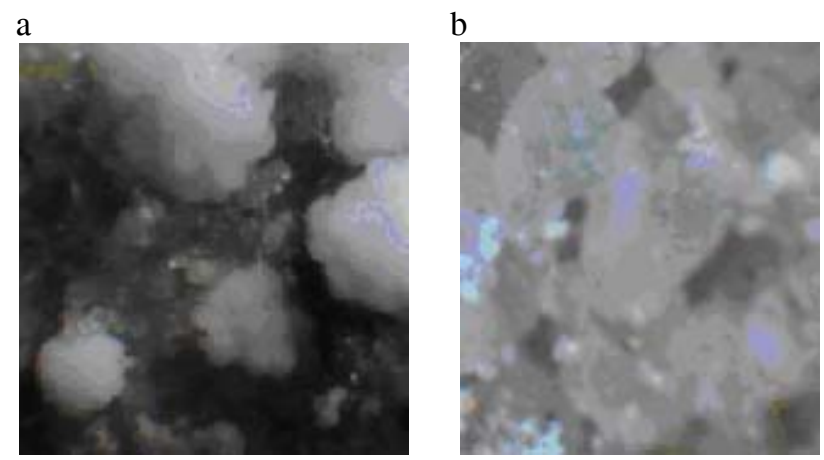

Fig 4. Surface roses formed by halite on another sandstone block, with nitrates in subbase, arch 9 (6x magnified, photo by M. Gregerová) (a); higher concentrations of nitrates on sandstone block, arch 9 (12x magnified, photo by M. Gregerová) (b)

The test holes (Fig 5) and analyses testify a considerable variability of the physical and mechanical, chemical, petrographic and mineralogical characteristics of the filling layers and stone blocks of the bridge structure. The trial holes show considerable differences not only in the quality, but also implementation, thickness and structural layout of the filling layers of the bridge body (Fig 6). The survey has proven that the differences in the moisture content of individual structural materials in relation to the intensity of local rainwater leakage are of great importance for the monitored properties (porosity, volume density, dilatometric properties, mechanical properties etc.) (Fig 7).

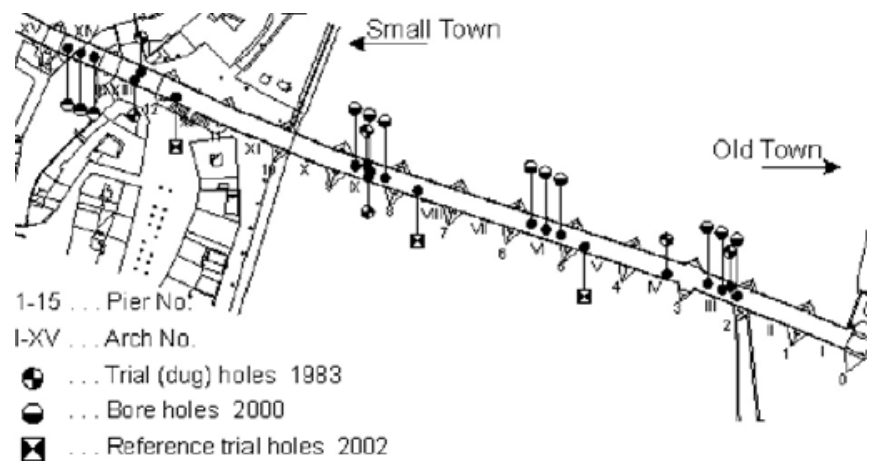

Fig 5. A scheme of test hole positioning in Charles Bridge body $(1983,2000,2002)$

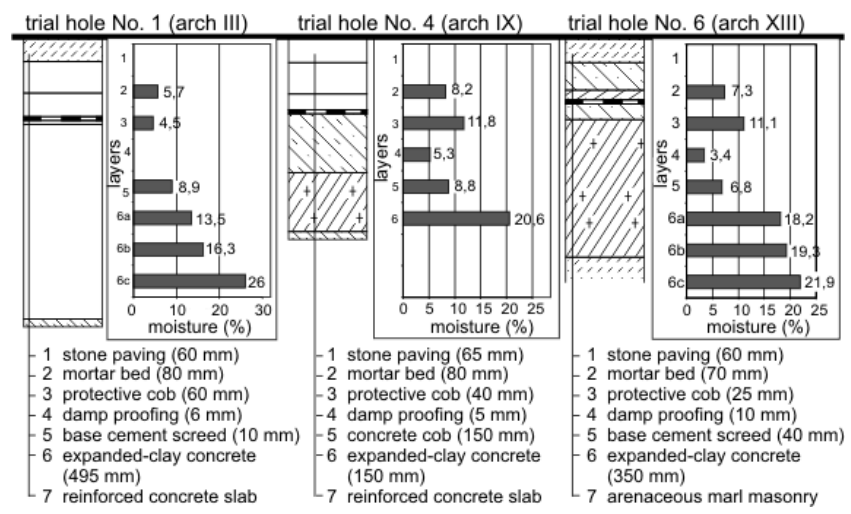

Fig 6. A scheme of bridge body layers and their moisture content as determined by dug test holes
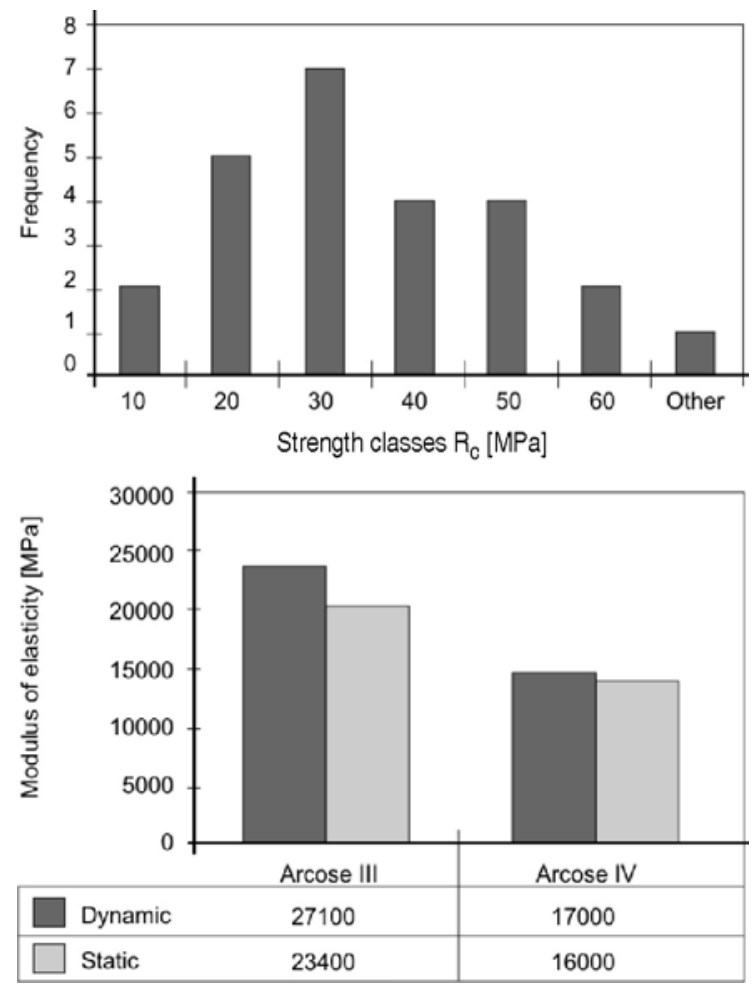

Fig 7. Bar chart of compressive strength frequency (a); mutual comparison of dynamic and static moduli of elasticity (b) 
Chemical degradation processes are also visible on the samples of modern-day filling layers, expanded-clay concrete and concrete used in the slab tie (Fig 8). Fig 9 displays time-related changes and the course of salt concentration in surface layers of building stone testifying the intensity of degradation processes. Fig 10 depicts the moisture content profile of the bridge body. The stone masonry surface clearly shows traces of the high moisture content of the bridge structure.
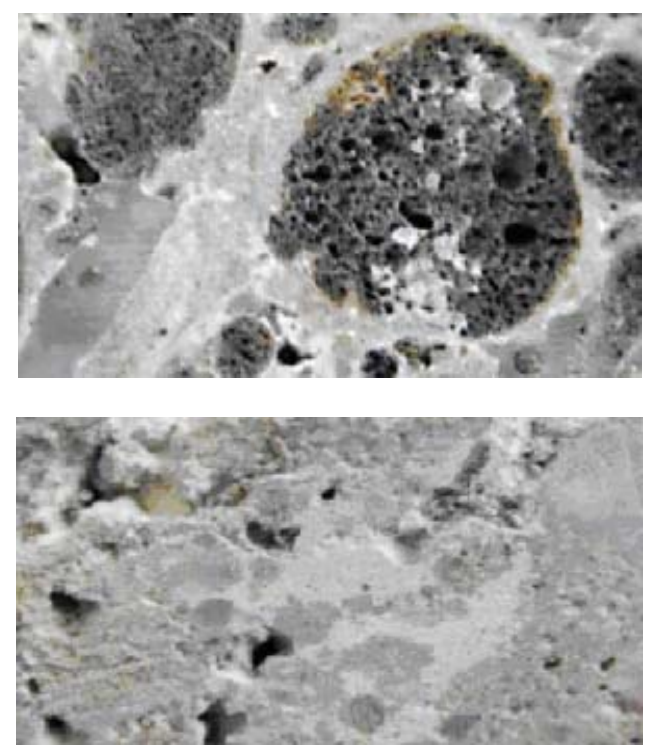

Fig 8. Expanded-clay concrete with thick white edges of secondary minerals, $1 \mathrm{~mm}$ thick (ettringite, thaumasite + calcite + gypsum) (a); reinforced concrete with thick locations of secondary minerals, $11 \mathrm{~mm}$ thick (ettringite, thaumasite + calcite + gypsum) (b)
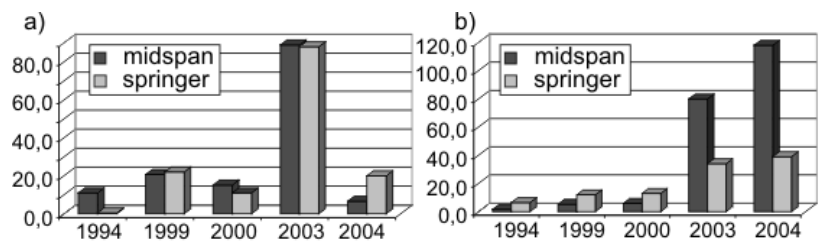

c)
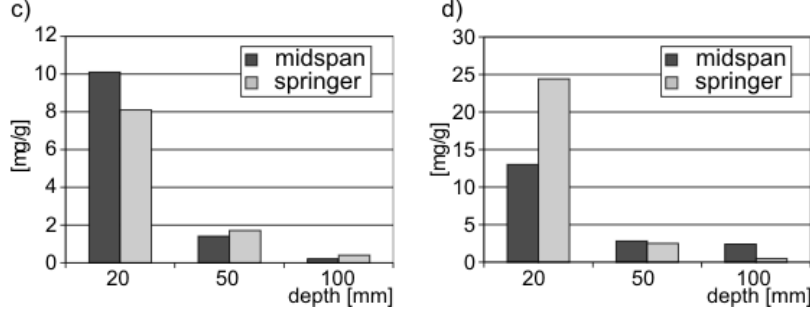

Fig 9. Concentrations of nitrogen salts in surface layer of sandstone block, arch VI - midspan, springer (a); concentrations of sulphates in surface layer of sandstone block, arch VI - midspan, springer (b); concentrations of $\mathrm{NO}_{3}$ and $\mathrm{SO}_{4}[\mathrm{mg} / \mathrm{g}]$ in sandstone blocks of Charles Bridge in relation to trial hole depth, arch III - springer (c); concentrations of $\mathrm{NO}_{3}$ and $\mathrm{SO}_{4}[\mathrm{mg} / \mathrm{g}]$ in sandstone blocks of Charles Bridge in relation to trial hole depth, arch IV springer (according to Wasserbauer) (d)

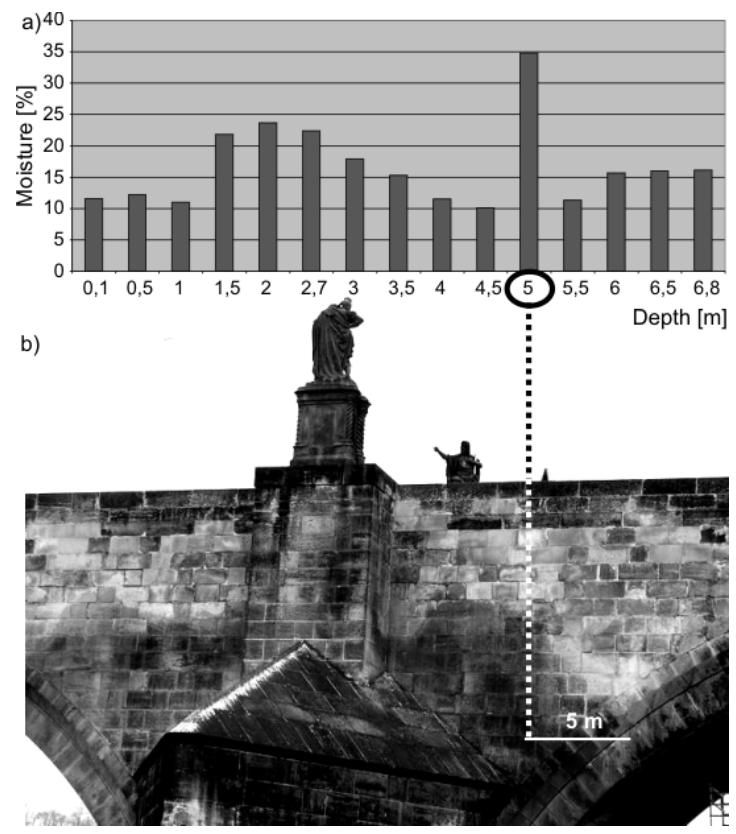

Fig 10. Moisture content-core hole depth relation (VJ 2) in arch III: a) moisture content of building materials determined by core holes; b) visually observable manifestations of increased moisture on breast wall surface

\section{Monitoring of deformations and strain of the stone bridge structure and breast walls}

The monitoring of deformations and strain of the stone bridge structure of Charles Bridge showed a cyclical strain in the stone bridge structure (vertical deformations of the bridge arches, horizontal and vertical deformations and tilt of the breast walls, changes in the crack width on the bridge vault facing) and their direct connection with temperature and moisture changes (Fig 11, 16).

Table 1 displays maximum values of deformations measured within an one-day $\left(\Delta_{\text {day }}\right)$, or a several months cycle $\left(\Delta_{\text {month }}\right)$.

Table 1. Maximum values of one-day and one-month deformations of the stone structure of Charles Bridge measured

\begin{tabular}{|c|c|c|c|c|c|}
\hline & \multicolumn{2}{|c|}{ Summer season } & \multicolumn{2}{|c|}{ Winter season } \\
\hline & & $\Delta_{\text {day }}$ & $\Delta_{\text {month }}$ & $\Delta_{\text {day }}$ & $\Delta_{\text {month }}$ \\
\hline \multicolumn{2}{|c|}{$\begin{array}{l}\text { Horizontal deformations of } \\
\text { breast wall tops }\left(\Delta_{\mathrm{x}}\right)(\mathrm{mm})\end{array}$} & $\pm 1,5$ & $\begin{array}{c}+2,5 \\
-3\end{array}$ & $\pm 1,4$ & \pm 2 \\
\hline \multicolumn{2}{|c|}{$\begin{array}{l}\text { Transverse tilts of breast } \\
\text { walls }(\varphi) \text { (seconds) }\end{array}$} & $\begin{array}{l}+42 \\
-79\end{array}$ & $\begin{array}{l}+210 \\
-100\end{array}$ & $\begin{array}{l}+100 \\
-75\end{array}$ & \pm 250 \\
\hline \multicolumn{2}{|c|}{$\begin{array}{l}\text { Vertical deformations of } \\
\text { breast wall tops (vertical } \\
\text { deformations of bridge } \\
\text { arches) }\left(\Delta_{\mathrm{y}}\right)(\mathrm{mm})\end{array}$} & $\begin{array}{l}+2,97 \\
-3,58\end{array}$ & $\begin{array}{r}+3 \\
-4\end{array}$ & \pm 4 & $\pm 1,5$ \\
\hline \multicolumn{2}{|c|}{$\begin{array}{l}\text { Change in width of longitu- } \\
\text { dinal cracks on bridge vault } \\
\text { facing }\left(\Delta_{x}\right)(\mu \mathrm{m})\end{array}$} & $\begin{array}{c}10 \\
\div \\
20\end{array}$ & $\begin{array}{c}200 \\
\div \\
420\end{array}$ & $\begin{array}{c}15 \\
\div \\
40\end{array}$ & $\begin{array}{c}400 \\
\div \\
700\end{array}$ \\
\hline Legend: & \multicolumn{5}{|c|}{$\begin{array}{l}\Delta_{\text {day }} \text { maximum deformation measured within } \\
\text { a one-day cycle } \\
\Delta_{\text {month maximum deformation measured within a }} \\
\text { several months' cycle }\end{array}$} \\
\hline
\end{tabular}




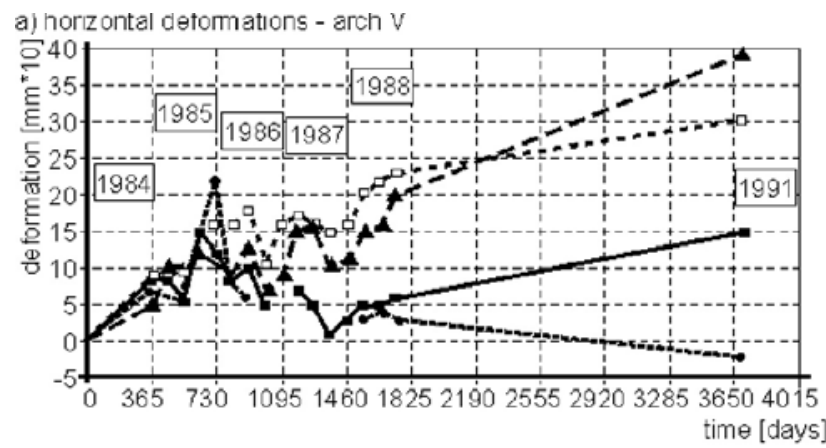

b) vertical deformations - arch $V$

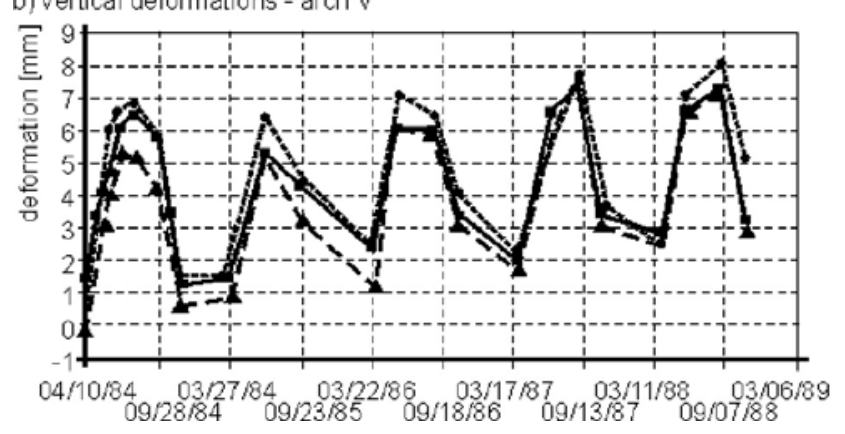

Fig 11. Experimentally measured horizontal deformations of opposite breast walls (a) and vertical deformations of bridge crown sections (b)

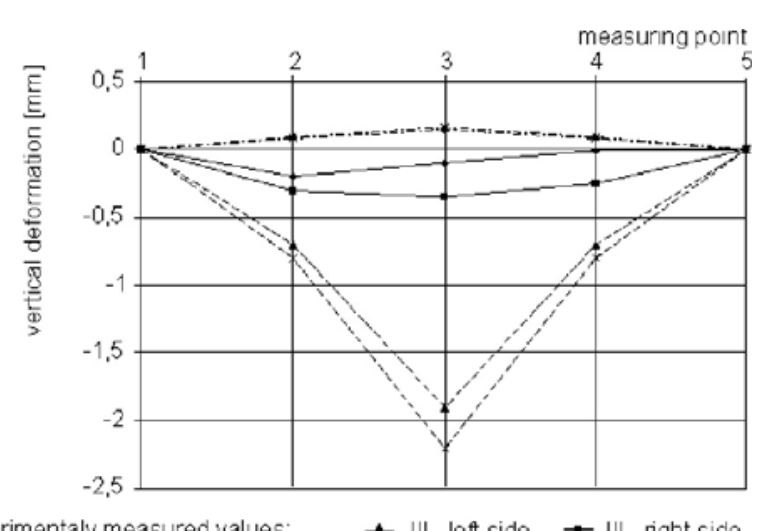

Experimentaly measured values: $\quad \rightarrow$ III., left side $\rightarrow$ III., right side

Theoretically calculated values:

- num. model \#1, dead load + infill layers $+1^{\circ} \mathrm{C}-x-$ num. model \#1, $+1^{\circ} \mathrm{C}$ $-*$ - num. model $\# 2$, dead load + infill layers $+1^{\circ} \mathrm{C}-$ num. model $\# 2,+1^{\circ} \mathrm{C}$

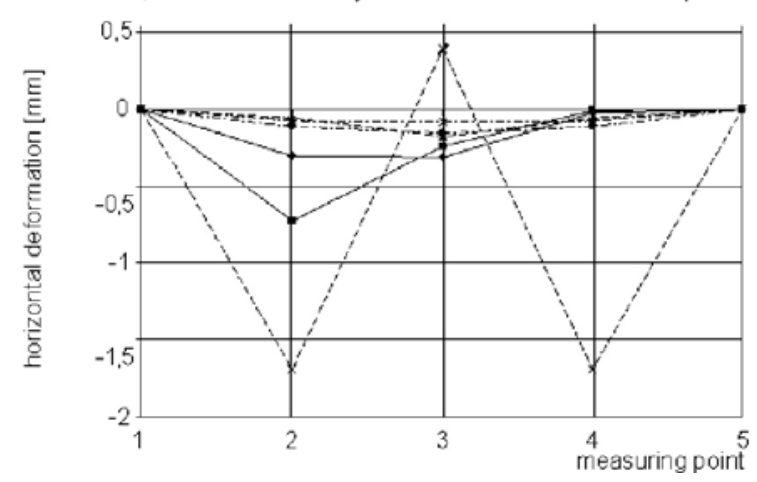

Fig 12. Comparison of vertical and horizontal deformations measured and theoretically calculated (arch III, for temperature difference of $+1{ }^{\circ} \mathrm{C}$ )
Fig 12 compares selected extreme values of theoretically calculated horizontal and vertical deformations of the upper edge (crest) of the breast walls due to the effects of temperature changes and deformations measured by using a laser spirit level.

The values of corresponding deformations theoretically calculated by means of approximative numerical analyses are in good line with discrete values obtained during the experimental monitoring.

During the all-year cycle, vertical deformations arise due to temperature changes - in the form of deflection and flattening of the stone bridge arch, which reach values ranging from $1 / 7500$ to $1 / 2500$ of the arch span at the arch crown, with the vertical deformation pattern corresponding to the course of outdoor temperatures in keeping with the respective season. The value of the difference between the measured vertical deformations given by the difference between the highest positive (deflection) and the lowest negative (drop, flattening) value lies within an interval of 2 to $10 \mathrm{~mm}$. The value of the difference between permanent vertical deformations reaches, eg in vault arch No XIV - 7,9 mm (difference between the measurements of $4 / 84$ and 9/88). The total values of permanent deformations (strain) of monitored vault arches tend to reach higher values in time (approx 0,4 to $0,7 \mathrm{~mm} /$ year), and result in a gradual degradation (cracking in masonry joints) and disintegration of the stone masonry (Fig $11 \mathrm{~b}$ ).

Experimental monitoring of the condition and development of cracks in the stone construction and the tilting of the breast walls of Charles Bridge (bridge arches V, VI and IX) proved that the monitored arches suffer from a gradual increase in the length of open cracks.

Crack development and strain in the stone masonry are encouraged by the non-constant temperature pattern along the cross-section of the massive bridge structure which causes cyclic shape changes in the bridge structure. The location of the thermal insulation layer of expandedclay concrete at the surface of the bridge body filling layers increases, namely during transitory seasons, on a short-term basis the temperature gradient along the crosssection of the bridge structure. In particular, it affects the temperature difference between the internal and external surface of the stone masonry and the temperature of the bridge body filling layers (Fig 13).

Cyclic vertical deformations of stone bridge arches due to the effect of temperature differences are inhibited by vertically laid out breast walls (the rise of shear cracks at the edges of vault arches in the crown area"extrusion" of vault arches).

Facing breast walls are locally degraded by cracks running along the heel bed joint between the arch and the wall, and by cracks in the bed joint at a level of the mortar bed and the protective concrete layer below the granite paving (in arch XIII a horizontal shift in the joint is evident as well, while in the area of degraded bed joints deposits of washed out salts can be seen, Fig 14). Prominent cracks may be observed on the interface between the end arches of the bridge vaults and parts of the attached bridge piers. The differences in the temperature along the 

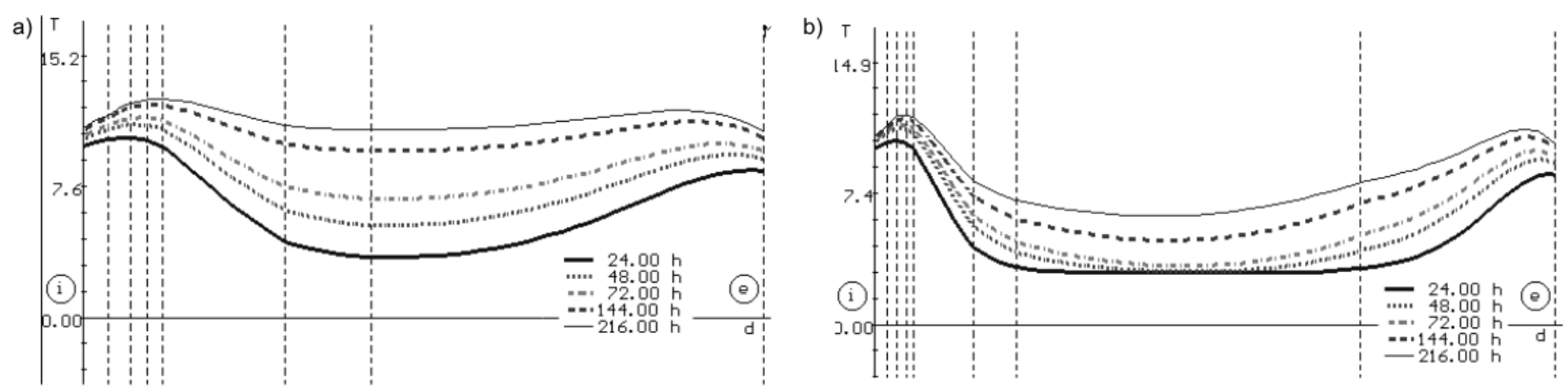

c)

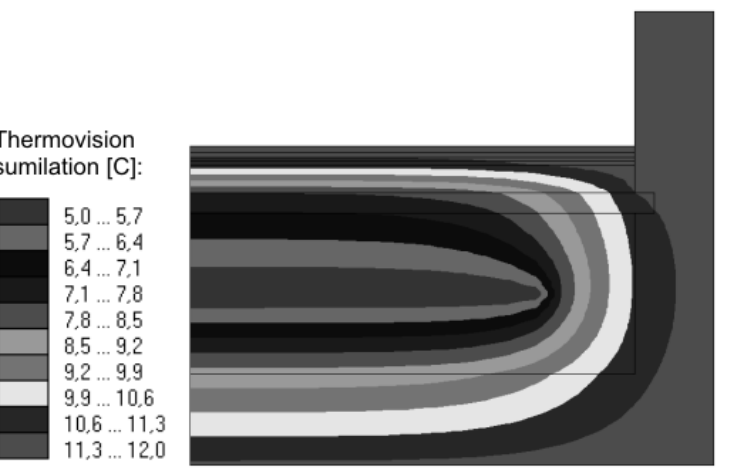

d)
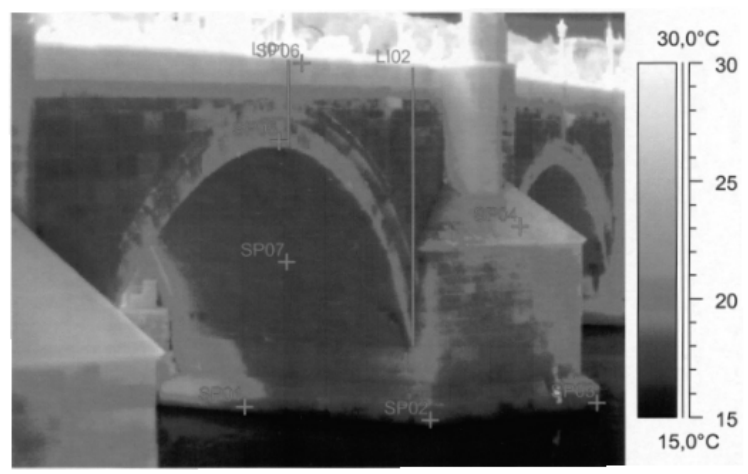

Fig 13. Temperature time pattern in reinforced concrete slab in the crown in spring (initial slab temperature $+3{ }^{\circ} \mathrm{C}$, average day temperature $12{ }^{\circ} \mathrm{C}$ with amplitude of $6{ }^{\circ} \mathrm{C}$ ) (a); ditto $1 / 3$ of arch span (b); reference temperature field $1 / 3$ of arch span - spring, $6^{\text {th }}$ day after temperature rise) $(\mathrm{c})$; surface temperatures of stone bridge structure $\left(\mathrm{t}_{\max }=25,1{ }^{\circ} \mathrm{C}, \mathrm{t}_{\min }=16,8^{\circ} \mathrm{C}\right.$; thermovision May 2003) (d)
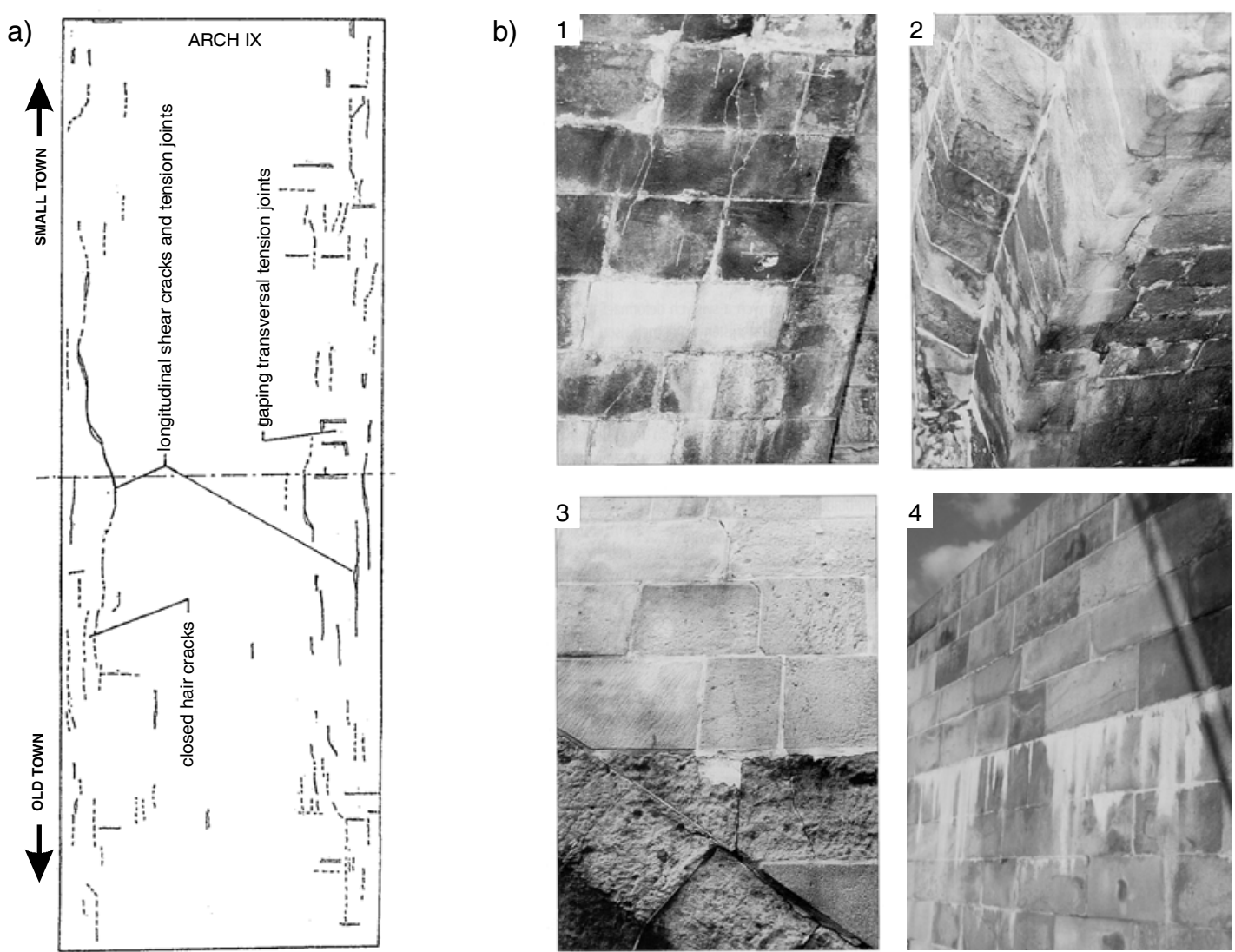

Fig 14. A scheme of tension joints and shear cracks in the face surface of vault arch IX (a); tension joints, rainwater seepage and salt sediments on the face surface of bridge vaults (1); vault masonry degradation in the area of breast wall embedment (2); cracks in the breast wall (3); washed out salts in the area of degraded bed joint (4) (b) 
cross-section of the stone bridge structure and its cyclic changes in time give rise to changes in the shape of the bridge structure accompanied by horizontal deformations of the breast walls (Fig $11 \mathrm{a}$ ).

The main sign of mechanical failures of the stone structure of Charles Bridge caused by cyclical temperature effects are mainly hair cracks visually observable on the face of vault arches developing to prominent longitudinal tension joints and shear cracks passing through both the joints of the stone masonry and the stone blocks. The extent and intensity of deterioration of the stone masonry of individual vault arches differ. Some vault arches are degraded by prominent longitudinal cracks with a width of up to several millimetres, which pass through several masonry layers and are mostly situated at the top, close to the vault edge, at the point of facing (breast) wall mounting. The growth and development of these cracks is related to vertical deformations of vault arches due to temperature changes during different seasons ("extrusion" of vault arches in summer - Fig 14 b). Other cracks, usually of local, non-continuous type, are situated in various places, and do not conform to any other traceable regularities (Fig 14 b).

A numerical analysis of the bridge arch proved the existence of transversal tensile stresses $\sigma_{y}$, namely in the bridge arch section adjoining the breast walls, caused by the effect of vertical load and temperature, which exceed the load-bearing capacity of the stone masonry in tension (Fig 15). Under the presumed coupling of the breast walls by means of a reinforcement concrete slab tie (design stage - repair 1966-1975), total deformations along the cross-section are reduced at the expense of a substantial increase in transversal tensile stresses $+\sigma_{y}$, which degrade the stone masonry by means of tension joints (Fig 14 a).

The growth of structural cracks, their propagation and successive degradation of the stone masonry due to cyclic effects of temperature and moisture is set off by reaching the critical and limit deformations, not by reaching the limit stress values. The history of this process of gradual degradation depends on the frequency and intensity of loading cycles, and, at the same time, on the scope of the elastic and elastoplastic zone in masonry. In the case of stone masonry, this scope is relatively narrow, being characterised by growing permanent deformations accompanied by the rise and development of tension joints and shear cracks, or by crushing the filler of bed joints and stone blocks, and by a gradual disintegration of masonry.

Experimental monitoring of the condition and development of cracks and the tilting of the breast walls (Figs 16, 17) in the stone structure of Charles Bridge proved that the monitored arches suffer from a gradual increase in the length of open cracks (Fig 16 b). Analogically, the latest survey has also revealed more distinctive values of horizontal deformations of the growing tilt of some breast walls against stagnant values (Fig 16 a).

\section{Numerical analysis of the stone bridge structure}

The results of a numerical analysis have proved that the interaction of the bridge arch with the breast walls and the bridge body filler (including pavement base courses) contributes to a gradual growth of tension joints in the stone arch masonry, in the breast walls and to their growing permanent horizontal deformation (tilting). A non-constant temperature time pattern along the crosssection of the massive stone bridge structure causes cyclic changes in shape, namely of transversal crosssections of the stone bridge structure, which are the cause of the appearance and development of cracking in the areas of tensile stresses and permanent deformations.

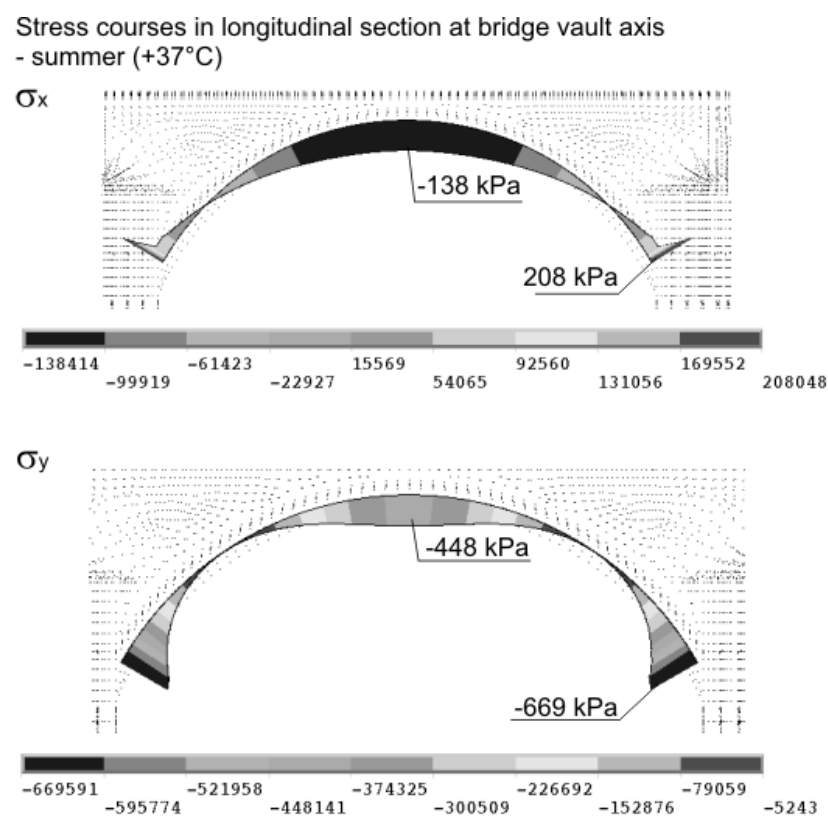

Stress courses in transverse section at bridge vault axis - winter $\left(-24^{\circ} \mathrm{C}\right)$
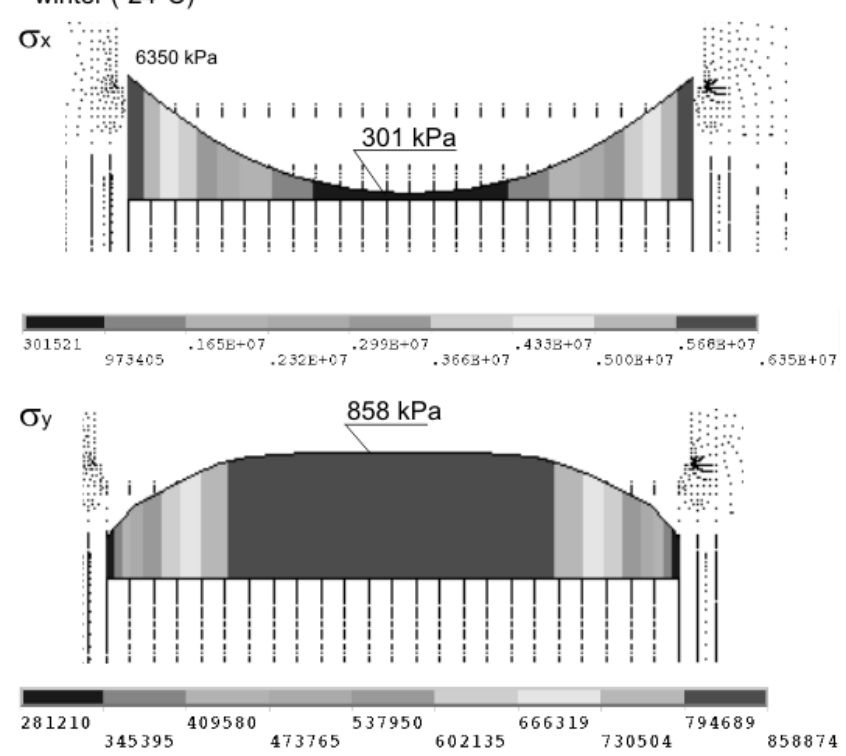

Fig 15. Time courses of normal stresses $s_{x}$ and $s_{y}$ in transversal (in vault crown) and longitudinal axis of the bridge vault for loading temperatures of $+37^{\circ} \mathrm{C}$ and $-24{ }^{\circ} \mathrm{C}$ 


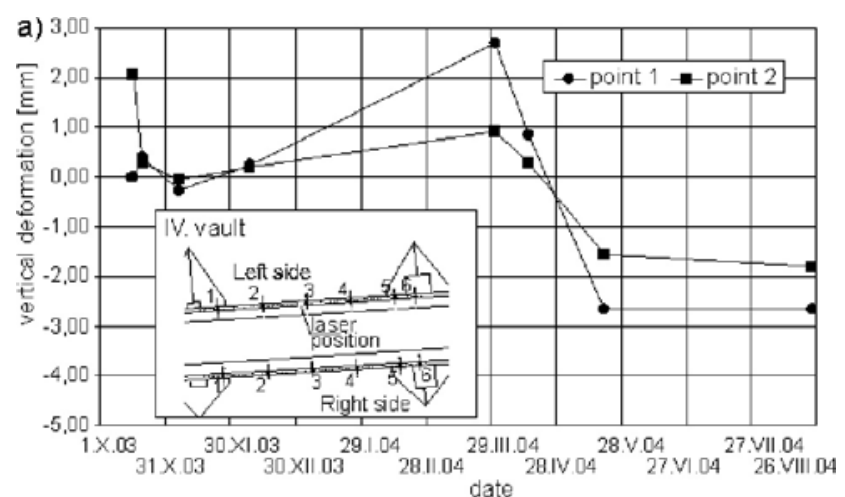

b)

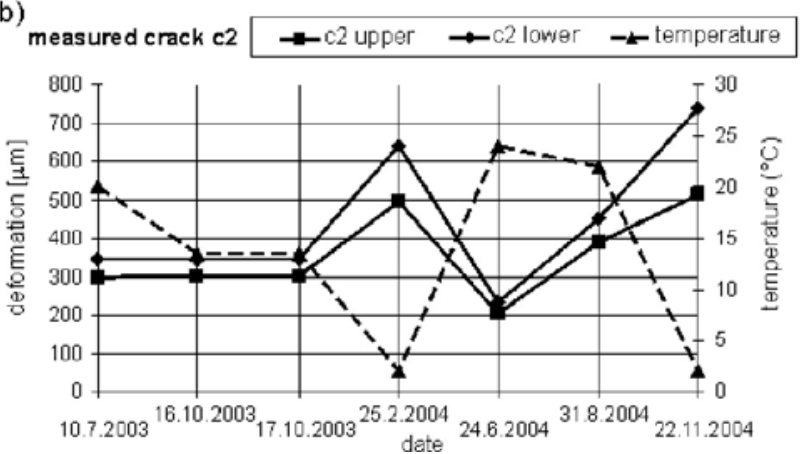

Fig 16. Transverse horizontal deformations of breast wall tops (arch IV) (a); changes in longitudinal crack width (b)
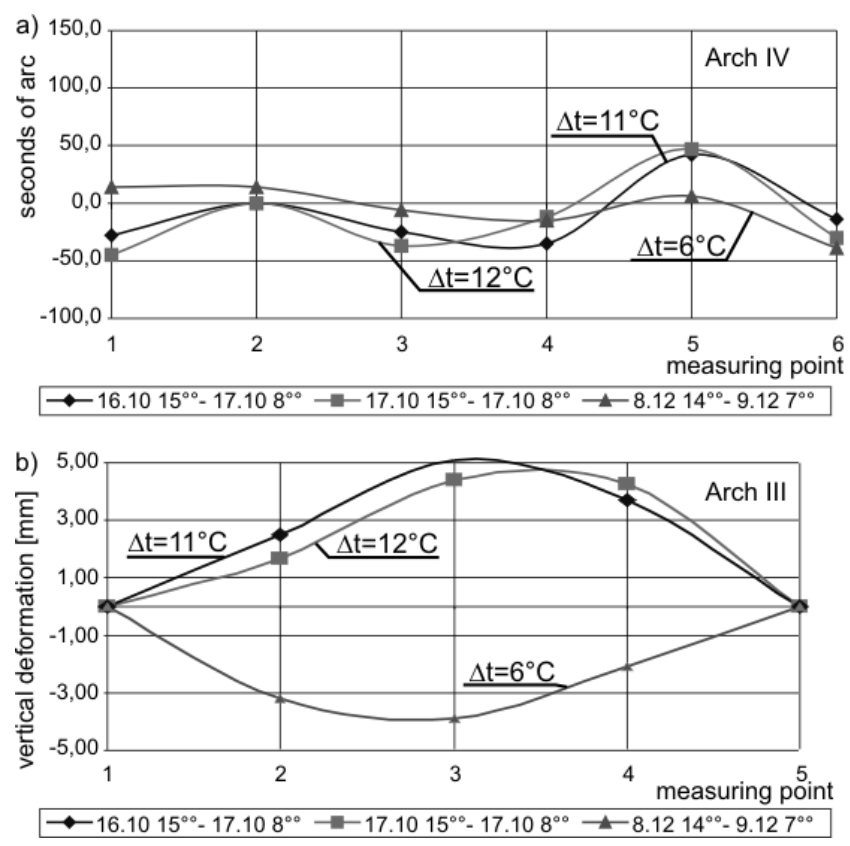

Fig 17. Transverse tilt of breast walls (a); vertical deformations of breast wall tops (b)

Fig 18 shows theoretically calculated characteristic shapes of the deformations of the breast wall and the bridge vault due to temperature effects $\left(+37^{\circ} \mathrm{C},-24^{\circ} \mathrm{C}\right)$ and the effect of dead weight. The deformation of the upper edge of the breast wall due to the temperature effect is implemented in the bridge structure already "deformed", which affects the course of the resulting deformation (Fig 18 b).

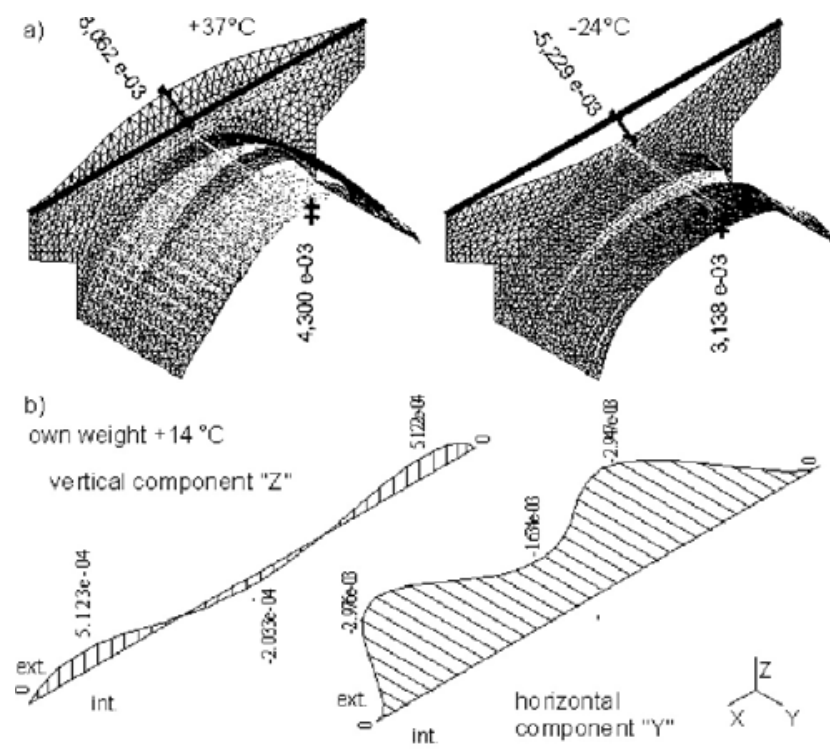

Fig 18. Theoretically calculated characteristic shapes of deformations of the breast wall and the bridge vault due to the temperature effect $\left(+37^{\circ} \mathrm{C},-24^{\circ} \mathrm{C}\right)$ and the dead weight effect (a); deformations of the upper edge of the breast wall due to the temperature effect (b)

The numerical analysis (FEM) has proven an unfavourable effect of coupling the breast walls with the reinforcement concrete slab tie, mainly in the area of the bridge arch crown, both in terms of extreme values of normal stresses in compression and tension $\left( \pm \sigma_{x}, \pm \sigma_{y}\right)$ and in terms of horizontal cyclic deformations (deflection $\Delta_{\mathrm{y}}$ ) of arch crowns due to temperature effects. The interaction of the bridge arch with the breast walls is characterised by a rise in transversal normal stresses $\pm \sigma_{y}$ and by a shift in the funicular (compression) line at the bridge vault's crown close to the arch edges (in the arch areas adjoining the breast walls), towards the upper face of the bridge arch, and thus by the rise of longitudinal tensile stresses $+\sigma_{\mathrm{x}}$ on the bridge vault's face. Transversal normal stresses $+\sigma_{\mathrm{y}}$ caused by the potential interaction of the bridge arch with the breast walls and by the effect of coupling the breast walls by means of the reinforcement concrete slab tie, are the main cause of the rise of transversal tensile stresses at the lower arch face. Longitudinal tensile stresses $+\sigma_{\mathrm{x}}$ at the arch crown cause an increase in the normal stresses in tension $-\sigma_{x}$ in the part of the resisting crosssection of the arch masonry.

A numerical analysis has proven that a relatively high rigidity of the stone bridge structure due to the mutual interaction of the bridge arches, the breast walls and filling layers, as compared to a "pure" arch structure, restricts its total deformations, being simultaneously the cause of increased stress, and it is in particular the tensile normal stresses (Fig 7) that cause the rise and development of cracks in the stone masonry of the bridge arches and the breast walls. In terms of preventing the appearance of mechanical failures and permanent deformations of the bridge structure, among the basic measures there is a removal of the spacing effect of the filling layers of the bridge body and limitation of the interaction of filling layers and the breast walls with an arch bridge structure. 


\section{Modification of the bridge body filler during the construction of new road pavements on stone bridges}

As part of reconstruction projects of historical stone bridge structures, including new road pavements and running surfaces, the original, relatively flexible fillers of the bridge body are replaced with more rigid base courses of pavements, including concrete raft-floor slabs. In some cases, these new structures are used to provide total strengthening the original vault stone bridge structure. In these cases, serious changes in the rigidity and strain properties of the original structure occur, characterised by a significant growth in its sensitivity to non-stress effects, mainly the effect of temperature.

In the case of a transversal deformation of the breast walls in the direction inside the bridge due to vertical load and temperature load (mainly the central part of the bridge vault) undesirable spacing effects of the concrete sub-base layer and the other filling layers of the bridge body occur, which are in active contact with the breast walls. After exceeding the shear strength in masonry joints, shear cracks and shifting of the breast wall in joints arise (Fig 14).

A high relative yielding to shear - low shear rigidity - of the inserted separation layer, as compared to the rigidity of the vault structure and the pavement itself, limits their mutual interaction and load transfer via shear forces, or via forced deformation and strain. A low shear rigidity of the separation layer, at the same time, substantially limits and reduces a gradual growth in permanent strain of the bridge structure. A release of a structural bond between the bridge vault structure and the bridge filler leads to a total decrease in loading eliminating at the same time, the appearance and development of permanent strain, failures and disintegration of namely the bridge vault structure.

Consistent separation of the bridge body filler from the breast walls by a continuous expansion joint (ca $50 \mathrm{~mm}$ in width) contributes to a significant reduction in transverse horizontal stresses acting on the breast walls due to lateral pressures exerted by individual bridge body filling layers and thus to the limitation of their transverse deformations and gradual tilt in the direction outside the bridge structure. By connecting the continuous expansion joints onto the ventilation system, the moisture content of the bridge body filling layers will be reduced.

The concept designed within [11] presumes "returning" the construction of Charles Bridge to its original shape, ie a stone bridge vault construction. It presumes the design of a structural system which will dramatically limit the mutual interaction of the stone bridge vault construction, the breast walls and the bridge pavement body due to the effects of volume changes, namely temperature and moisture effects, eliminating and substantially limiting the causes of physical, chemical and microbiological corrosive and degradation processes.

As implied by this requirement, the bridge pavement structure, including damp proofing and the meshreinforced concrete raft floor, must be laid onto the stone vault bridge structure in a "flexible" way using a "separation" layer yielding to shear, and it must be separated, together with the other bridge filling layers, from the breast walls by a continuous expansion joint (Fig 19).

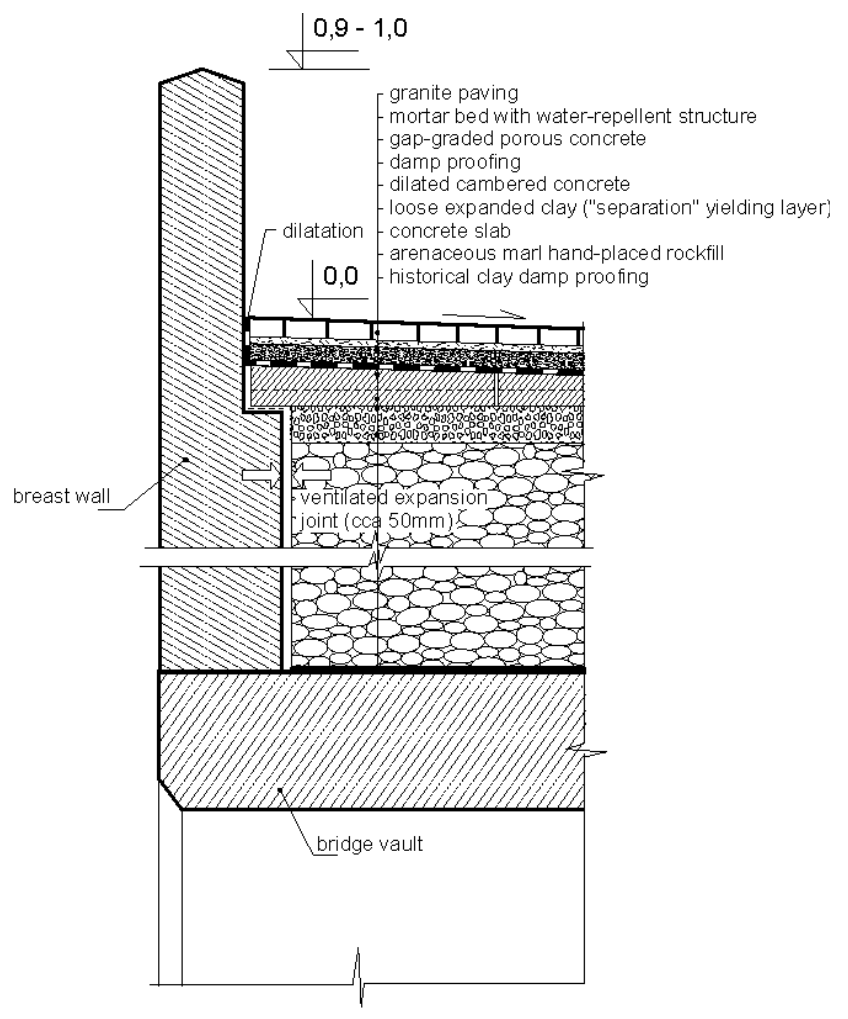

Fig 19. Concept of reconstruction of stone bridge body

\section{Acknowledgement}

This article was written with support of the research project VZ1 MSM 6840770001 "Reliability, optimization and durability of building materials and structures".

\section{References}

1. GÜLKER, G.; HELMERS, H.; HINSCH, K. D.; MEINLSCHMIDT, P. and WOLFF, K. Deformation mapping and surface inspection of historical monuments. Optics and Lasers in Engineering, 1996, 24(2-3), p. 183-213.

2. LI, Z. X.; CHAN, T. H. T. and KO, J. M. Fatigue analysis and life prediction of bridges with structural health monitoring data - Part I: methodology and strategy. International Journal of Fatigue, Jan 2001, 23(1), p. 45-53.

3. PONNIAH, D. A. and PRENTICE, D. J. Long term monitoring of fill pressures in a new brickwork arch bridge. Construction and Building Materials, Apr 1999, 13(3), p. 159-167.

4. GRINZATO, E.; BIZON, P. G. and MARINETTI, S. Monitoring of ancient buildings by the thermal method. Journal of Cultural Heritage, Apr 2002, 3(1), p. 21-29.

5. SANDROLINI, F. and FRANZONI, E. An operative protocol for reliable measurements of moisture in porous materials of ancient buildings. Building and Environment, Oct 2006, 41(10), p. 1372-1380.

6. LOURENCO, P. B.; KRAKOWIAK, K. J.; FERNANDES, F. M. and RAMOS, L. F. Failure analysis of Monastery of Jeronimos, Lisbon: How to learn from sophisticated numerical models. Engineering Failure Analysis, 2007, 14(2), p. 280-300. 
7. WITZANY, J. et al. Assessment of current structural and maintenance condition of Charles Bridge. Stavebni obzor (Civil Engineering Journal), 2002, 8, p. 225-249 (in Czech).

8. WITZANY, J. et al. Comprehensive assessment of a theoretical and experimental investigation of Charles Bridge 1994 to 2004 (Part 1). Stavebni obzor (Civil Engineering Journal), 2005, 3, p. 65-83 (in Czech).

9. WITZANY, J. et al. Comprehensive assessment of a theoretical and experimental investigation of Charles Bridge
1994 to 2004 (Part 2). Stavebni obzor (Civil Engineering Journal), 2005, 4, p. 97-105 (in Czech).

10. WITZANY, J. and JÄGER W. Die Karlsbrücke in Prag, Bewertung des bautechnischen Zustandes. Mauerwerk, 2005, 9(3), p. 108-119 (in German).

11. WITZANY, J. Construction conditions and reconstruction of Charles Bridge. Inzenyrska komora (CKAIT Journal), 1997, Special issue, p. 8-19 (in Czech).

\section{KLIMATINIŲ POVEIKIŲ ĮTAKOS MŪRINIO ISTORINIO TILTO KONSTRUKCIJOMS ANALIZE் (PRIEŽIŪRA, TEORINĖ ANALIZĖ, REMONTAS)}

\section{J. Witzany, R. Zigler}

\section{Santrauka}

Cikliniai temperatūros ir drègmès poveikiai mūrinių tiltų konstrukcijose sukelia papildomas deformacijas, laipsnišką ilgalaikių deformacijų augimą, plyšių vystymąsi. Šie veiksniai lemia tilto skliautų mūro skilimą. Padaryta XIV amžiuje statyto Karlo mūrinio tilto Prahoje klimatinių poveikių sukelto įtempių ir deformacijų būvio analizè. Atlikti šio tilto antstato ir skliautų deformacijų natūriniai stebejjimai. Teoriniai ir eksperimentiniai tyrimai parodè, kad temperatūros ir drègmès pokyčiai turi didelę įtaką tilto konstrukcijų itempių ir deformacijų būviui. Klimatinių poveikiu įtaka tilto elgsenai labai priklauso ir nuo skliautų, ir antstato užpildymo sąveikos. Itin daug dėmesio reikia skirti antstato užpildymo sluoksnių storiui. Atlikus istorinių mūrinių tiltų konstrukcijų remontą standartinèmis technologijomis, bendrasis tilto konstrukcijos standumas padideja, drauge jis tampa jautresnis klimatiniams temperatūros ir drègmės poveikiams.

Reikšminiai žodžiai: cikliniai poveikiai, ilgalaikès deformacijos, skilimas, klimatiniai poveikiai, sąveika, drègmè.

Jiří WITZANY. Dr Sc, Rector, Prof Ing Emeritus, Head of Dept of Building Structures, chief researcher of research plan "Reliability, optimisation and durability of building materials and structures" and grant project "Reliability analysis of characteristics of building materials and structures with regard to their time-related changes and time-variable effects". He devotes himself to structural problems of designing building structures, and has carried out extensive theoretic and experimental research of prefabricated structures, reconstruction and rehabilitation designs of concrete and masonry buildings, degradation processes, durability and reliability of buildings. He has elaborated the reconstruction concept of Charles Bridge.

Radek ZIGLER. PhD Ing Assistant Lecturer at the Dept of Bulding Structures, Faculty of Civil Engineering, Czech Technical University in Prague, Czech Republic. His research interests include structural analyses, mainly of masonry and precast conrete structures, reconstructions and renovations of buildings etc. 